\title{
Nexus between Gender and Language Shift among the Youth in Nairobi County, Kenya
}

Rosemary Wamaitha Kimani*, Naom Moraa Nyarigoti, Moses Gatambuki Gathigia

Department of Languages, Karatina University, Kenya, P.O. Box 1957-10101, Karatina, Kenya

Corresponding Author: Rosemary Wamaitha Kimani, E-mail: rosewapius@gmail.com

\section{ARTICLE INFO}

Article history

Received: April 10, 2018

Accepted: July 07, 2018

Published: August 31, 2018

Volume: 9 Issue: 4

Advance access: July 2018

Conflicts of interest: None

Funding: None

\section{Key words:}

Language Shift,

Gender,

Youth,

Mother Tongue,

Sheng,

Kiswahili,

English

\begin{abstract}
The phenomenon of language shift is brought about by language contact. Language shift from mother tongue to another language among the youth is an issue that cannot be wished away due to, inter alia, factors like urbanization, migration, multilingualism or bilingualism and the country's language policy. Studies have also shown that there is notable difference in the use of language along gender lines. The objective of this study, therefore, is to assess the nexus between the gender variable and language shift among the youth in Nairobi County, Kenya. The study is anchored on a sociolinguistic theory known as the Domain Theory. The study adopted the ex-post facto research design. The study targeted students in public day secondary schools in Nairobi County, Kenya. The sample size of the study comprised 98 students drawn from public day secondary schools in three sub-counties in Nairobi County. Questionnaires were used as the tools of data collection. The reliability of the tool was computed using the Cronbach's coefficient method with a reliability coefficient of 0.83 . Descriptive statistics was used to describe the findings of the data. Chi-square tests were conducted to establish the relationship between gender and language shift. There was a significant relationship $(\chi 2=18.143, p<0.05)$ between gender and the language used in communication with students of the same sex. There was also a significant relationship $(\chi 2=13.144, \mathrm{p}<0.005)$ between gender and the language used at school. The findings also show that majority of those who use Kiswahili (62\%), Sheng (100\%), English and Sheng $(100 \%)$ or Kiswahili and Sheng $(100 \%)$ are males. The findings, therefore, show that female and male students use languages differently and therefore, language shift occurred differently between the two genders. The findings, therefore, imply that in schools, female students are more likely to use English while male students are more likely to use Sheng. Kiswahili is used equally among males and females while mother tongue is not used at all. The study concludes that gender plays a significant role in language shift among the youth in Nairobi County. The study recommends that the Ministry of Education reviews the current language policy to include instructions in mother tongue in secondary schools.
\end{abstract}

\section{INTRODUCTION}

The field of language shift forms a central topic on sociolinguistics and linguistic anthropology. Trudgill (2003) defines sociolinguistics as an area of language in society which includes the following areas: dialectology, secular linguistics, anthropological linguistics, language contact studies, ethnography of speaking, discourse analysis, geolinguistics, the social psychology of language and the sociology of language. Language shift is one of the cardinal concerns of sociolinguistics. Language shift falls under language contact studies and was introduced to the realm of sociolinguistics by the studies of Joshua Fishman and Uriel Weinrich (Tsitsipis, 1998).

Language shift is one of the consequences of language contact. Language shift is the replacement of one or more languages in a community's repertoire by a language which is considered socially more powerful. According to Fishman (2004), language shift is the loss of a minority language in the context of immigrants adapting to the dominant language of their destination country. Tsitsipis (1998) argues that language shift involves change to both structural and functional aspects of the language. Thus, the shifting of indigenous languages is affected in varying degrees in respect to the grammatical, phonological and lexical resources, whereas their functional pragmatic roles are changed in a dialectical way with the expanding social role and use of the dominant languages. Ortman and Stevens (2008) posit that the process of language shift follows two patterns: intra-generational language shift and inter-generational shift. Intra-generational language shift occurs when people shift to use of the dominant language with time while inter-generational shift occurs when the language repertoire of children fails to match that of their parents. This is exemplified in the loss of Spanish among the Hispanic Americans.

In Kenya, the language policy in education puts premium on English as the main medium of instruction in the urban

Published by Australian International Academic Centre PTY.LTD.

Copyright (c) the author(s). This is an open access article under CC BY license (https://creativecommons.org/licenses/by/4.0/) http://dx.doi.org/10.7575/aiac.alls.v.9n.4p.206 
areas at all levels of education. In rural areas where there is linguistic homogeneity, the language policy identifies indigenous languages as the initial language of instruction in education (Batibo, 2005). In multi - ethnic regions, Kiswahili is used up to third grade after which it becomes a subject in the curriculum. For its instrumental role, English is encouraged in public domains. Furthermore, the drafting of a new constitution in 2010 that replaced the independence constitution has also served the role of creating a national identification for Kenya. To create this nationalism, the Kiswahili language has emerged as the language of solidarity that partially combats the colonial legacy of English as a prestige language (Githiora, 2002). Mother tongue shift in Kenya is also promoted by the fact that Kenya practises what is called subtractive bilingualism (Batibo, 2005). According to Fishman (2004), subtractive bilingualism is the practice where the learning of a second language interferes with the first language. In Kenya, the promotion of English to official position has led to subtractive bilingualism where children learn a second language (English) and lose their first language. Batibo (2005) argues that the fact that the government has not assigned any public function to the ethnic languages complicates the matter even further. Indeed, the Kenyan government does not support indigenous languages in disseminating public information for fear of stoking ethnic divisions. Instead, such communication comes from private enterprises which are criticized as sites for hate speech. This complicates further the issue of maintenance of the indigenous languages. According to Batibo (2005), out of the 56 indigenous languages, about 13 are highly endangered while a dozen are either extinct or nearly extinct. Brenzinger, Heine and Sommer (1991) report that in the Kenyan situation eight languages are extinct while five are in the process of extinction.

There is a recognizable difference in the use of language along gender lines. Holmes (as cited in Wardhaugh, 2006) lists five testable claims on language and gender: that women tend to use linguistic devices that stress solidarity more often than men do; women and men develop different patterns of language use; women tend to pay attention on the affective functions of an interaction more often than men do; women tend to interact in ways which will maintain and increase solidarity, while men tend to interact in ways which will maintain and increase their power and status. It is also important to note that the relevance of gender and/or sex roles have been noted in the transmission of languages in situations of language contact (Winter \& Pauwels, 2005). The broadest generalization is that women are at the vanguard of change in monolingual settings (Eckert \& McConnell-Ginet, 2003; Labov, 2001). Sociolinguists are also concerned with how gender affects their language use. For instance, men tend to interrupt women more often than vice versa; women use features more frequently that provide support and encouragement for other speakers; women use more hedges and tag questions to weaken their utterances; and women tend to pay more compliments (Meshtrie, Swann, Deumert \& Leap, 2009).

Indeed, the phenomenon of language dates back to historical issues such as migration, urbanization, economical, and political dominance among others. In Nairobi County, for example, urbanization, multilingualism or bilingualism, government language policy and inter-cultural marriages are some of the factors threatening the survival of the ethnic languages. Moreover, the fact that some of the youth are born and bred in the city creates a situation where they have minimal or no contact with their parents' ethnic languages. This has resulted to a generation of children with little proficiency in their ethnic languages. It is, therefore, against this backdrop that this study investigates the nexus between the gender variable on language shift among the youth in Nairobi County, Kenya. This is because studies have shown that there is a notable difference in the use of language along gender lines.

\section{LITERATURE REVIEW}

This study reviews literature on gender and language shift across the globe. Clyne (2003), for example, looks at the language contact between immigrant languages in Australia. The languages discussed are Spanish, Dutch, Italian, German, Hungarian, Croatian and Vietnamese. Clyne explains how and why the languages change and why some survive longer than others in the Australian context. Clyne argues that established linear models cannot cover the dynamics of language contact. The study also notes that in more established communities, older males shift to dominant languages faster than older women. This is attributed to the traditional roles which see males going out to work and women staying at home to raise the family. Clyne's study informs the current study in that it supports the role of gender in language shift; however, it is different in that it is limited to immigrant languages. The current study assesses the nexus between gender and language shift among the youth in Nairobi County, Kenya.

The purpose of Hamdani's (2012) study is to analyse the dynamics of language choice and the gender variable. The sample size of Hamdani's study is 134 (81 females and 53 males) students at the University of Garut: the third and first grade students of Pharmacy and Management Programmes. The students were given 10 questions on the use of language towards their males and females friends. The study noted that there is an influence of gender in determining the language choice of teenagers. The study also noted that there is no specific difference between males and females as far as code switching is concerned. However, it emerged that females were more likely to use code-mixing than males. The study is, therefore, similar to the current study in that it establishes the nexus between gender and language shift, but it is different in that the present study only focuses on students in public day schools in Nairobi County, Kenya.

Babane and Chauke (2016) undertake surveys with 30 participants through observation and interviews with the goal of understanding the factors that influence the speakers of Xitsonga to shift from their language to English and Northern Sotho. The study notes that both external and internal factors contribute to the language shift. The study also found that language shift by individuals is either permanent or temporary and is caused by linguistic mobility. Babane 
and Chauke conclude that the status of English in terms of privileges, prestige, rights, and power is more superior to the other languages and this influences them to shift from their languages to English in South Africa. Babane and Chauke's study is relevant to the current study in that it provides empirical evidence of language shift. However, it differs in that it was conducted in South Africa which has a different social-cultural fabric to that of Kenya.

In Kenya, Bartoo (2009) examines the linguistic social integration of Somali refugee teenagers in Eastleigh, a suburb within Nairobi City in Kenya. The study analyses descriptively the social networks along with domain analysis in order to discuss the concept of language shift by the teenagers having moved from a monolingual Somali to multilingual Kenya. The study is based on questionnaires, interviews and observations of 30 participants who were selected using the snow ball sampling technique. The study noted that the teenagers have multiplex and dense social networks which are Kenyan and Somalian based. These networks have enabled the Somali teenagers to retain the Somali language to a large extent and have also made them acquire other languages which are used in Kenya: English, Kiswahili and Sheng. The study is, therefore, similar to the current study in that it establishes the relationship English, Kiswahili and Sheng have in Kenya. However, it is different in that the present study only focuses on students in public day secondary schools in Nairobi County, Kenya.

Generally, the reviewed studies have informed the present study in terms of the structure, theory and methodology. However, they have not discussed in details the relationship between gender and language shift among students in public day secondary schools in Nairobi County, Kenya. Moreover, the reviewed studies have not examined the demographic variable of gender and its influence on language shift among the youth in Nairobi County, Kenya. These shortcomings have left research gaps and, therefore, the need to undertake the present study.

\section{THEORETICAL FRAMEWORK}

The study is anchored on a sociolinguistic theory known as the Domain Theory. The Domain Theory was introduced by Schmidt - Rohr and posits that language cannot be studied without the social context in which communication takes place. That is, the way the members in a society choose varieties of a language or switch towards another language determines the influence of social factors on language choice. In Fishman's version of the Domain Theory of language, domains are described as constructs that explain language and which are supposed to be a more powerful explanatory tool than the observable parameters like topic, place, and interlocutor (Fishman, 1972, 1977). Fishman (1977) examines the use of languages in different institutional contexts in a multilingual community. That is, "domains attempt to designate the major clusters of interaction situations that occur in particular multilingual settings' (p. 19). Fishman further states that there are five domains of language use which include: family, friendship, religion, education, and employment. The Domain Theory informs this study because
Nairobi County, a multilingual society, presents different domains such as family, school, church, government offices and social institutions. These domains demand different languages especially among the youth. In most cases, English and Kiswahili are preferred in formal domains while Sheng and Kiswahili dominate at home and peer activities. This pattern isolates the indigenous languages which are not assigned a domain for use or function among the youth. The Domain Theory, therefore, helps to explain the reason why there is a likelihood of language shift away from the ethnic languages in Nairobi County, Kenya.

\section{RESEARCH METHODOLOGY}

This study employed the ex-post facto research design. The ex-post facto design is appropriate where the researcher only describes the state of affairs as it exists at present (Kothari, 2004). In the current study, the researcher investigates and describes the phenomenon of language shift among the youth in Nairobi County, Kenya. This is a matter of choice and preference; hence, the applicability of the ex-post facto design.

The population of the study included students in public day secondary schools in three sub-counties in Nairobi County, Kenya. Public day schools were preferred for this study because their catchment area is Nairobi, unlike boarding schools which can admit students from all over the country. The three sub-counties investigated in this study include: Kamukunji, Starehe and Njiru. Kamukunji and Starehe sub-counties are, on one hand, situated at the centre of Nairobi County. They also have a better representation of the public day schools compared to other sub-counties. Njiru sub-county on the other hand is more peripheral but has the highest number of public day schools in Nairobi County. Records from the County Director of Education office indicated that there are 22 public day and 6 public boarding secondary schools in the area of study. The target population for this study is, therefore, the 8692 students in the 22 public day schools in Kamukunji, Starehe and Njiru sub-counties of Nairobi County, Kenya.

In this study, stratified and simple random sampling procedures are employed. The starting point was to determine the number of schools whose students would participate in the study. The schools (see Table 1) are stratified according to their sub-counties, that is, day schools at Kamukunji, Starehe and Njiru. According to Mugenda and Mugenda (2003), 30\% of the target population is adequate in a descriptive survey. Consequently, $30 \%$ of 22 is seven schools. The seven schools were selected using the simple random sampling in the ratio of 2:2:3. This ratio is preferred because Kamukunji and Starehe sub-counties have six and seven public day schools respectively, but with a higher student population than Njiru sub-county which has nine public day schools but a lower population. From each of the sampled schools, 14 form three students were sampled through simple random. This class was selected because the form one's and two's were considered to be relatively young and new to the school system and it was concluded that they might not give reliable data, while the form fours were assumed to be busy preparing their final 
exams and might give inaccurate information. Consequently, 98 students were included in the study.

Data was collected using questionnaires for students. According to Kathuri and Pals (1993), questionnaires are the best instruments in a survey research as they help in gathering data pertaining to opinions, attitude, preferences and perceptions. Language shift is a consequence of attitude and choice; hence, questionnaire was considered an appropriate tool for this study. The questionnaire was structured into three sections: Section A helped us identify the gender of the participants, ethnicity and language preference. Section B investigated the use of ethnic language and language choice in different domains while Section $\mathrm{C}$ was a Likert scale to capture the attitude of the respondents towards the mother tongue.

The study also tested the validity of the questionnaires. Airasian and Gray (2000) explain that validity addresses the problem of whether one is measuring suitable indicators of the concept and the accuracy of the results to the extent of what it is supposed to measure. The instrument is normally validated by making sure that the items to be tested are in line with the objectives of the study. Validation is further enhanced through piloting of the instrument. According to Murray (2003), piloting is crucial because it assists in the identification of ambiguous items and vague questions for improvement. Orodho (2005) recommends that the sample to be used in the pilot study should be equal to $10 \%$ of the sample in the main study. Therefore, 10 students drawn from 2 schools were involved in the study. However, the participants in the pilot did not participate in the main study.

To establish validity of the current instruments, the data collected from the pilot study was used to compute the reliability of the instrument. Reliability simply refers to the extent to which an instrument can generate similar results when used two or more times to gather data from a given population (Leedy \& Ormrod, 2005). The Cronbach's coefficient method was used to determine the internal consistency of the item. This method was employed owing to the fact that it requires only a single administration of the instrument (Cohen \& Swerdlik, 2005). Thus, the items were considered reliable if the scale produced a reliability coefficient of 0.7 and above. This reliability coefficient is normally considered appropriate for consistency levels (Fraenkel \& Wallen, 2000). A reliability coefficient of 0.83 was achieved in this study.

The raw data collected was classified according to attributes. In this study, attributes are the languages chosen in different contexts or domains. These languages include English, Kiswahili, mother tongue and Sheng. The quantitative data was coded, tabulated and analyzed using descriptive and thematic statistics such as frequency counts, mean and percentages. The qualitative data was organized in major themes and used to make conclusions that help to answer the research questions. Chi-square tests were conducted to establish relationships between gender and the use of mother tongue in social and formal domains. SPSS version 22 for windows was used in analysis. The findings were presented in form of Tables 1-4 and Figure 1.

\section{FINDINGS AND DISCUSSION}

In this section, we discuss the response rate of the participants, the gender of the students, the findings and discussion of the findings.

Table 1. Distribution of public secondary schools in the three sub-counties of Nairobi County, Kenya, in 2016

\begin{tabular}{lccc}
\hline District & $\begin{array}{c}\text { Public day } \\
\text { schools }\end{array}$ & $\begin{array}{c}\text { Student } \\
\text { population }\end{array}$ & $\begin{array}{c}\text { Teacher } \\
\text { population }\end{array}$ \\
\hline Kamukunji & 6 & 3197 & 135 \\
Starehe & 7 & 2803 & 111 \\
Njiru & 9 & 2692 & 73 \\
Total & 22 & 8692 & 319 \\
\hline
\end{tabular}

Table 2. Chi-Square tests between the gender variable and language shift

\begin{tabular}{lccc}
\hline & $\chi^{2}$ & Df & Sig. \\
\hline $\begin{array}{l}\text { Language used by students in } \\
\text { communication with friends of same } \\
\text { sex }\end{array}$ & 18.143 & 2 & $0.000^{* *}$ \\
$\begin{array}{l}\text { Language used by students in } \\
\text { communication with friends of }\end{array}$ & 2.169 & 2 & 0.338 \\
opposite sex & & & \\
Use of mother tongue & 1.18 & 1 & 0.277 \\
$\begin{array}{l}\text { Language used at home } \\
\text { Language used at church }\end{array}$ & 10.482 & 8 & 0.233 \\
Language used at school & 6.664 & 3 & 0.083 \\
\hline
\end{tabular}

Table 3. Cross tabulation of gender and language used between same sex members

\begin{tabular}{|c|c|c|c|c|c|c|}
\hline \multirow[t]{3}{*}{ Gender } & \multicolumn{6}{|c|}{ Language used } \\
\hline & \multicolumn{2}{|c|}{ English } & \multicolumn{2}{|c|}{ Kiswahili } & \multicolumn{2}{|c|}{ Sheng } \\
\hline & $\mathbf{N}$ & $\%$ & $\mathbf{N}$ & $\%$ & $\mathbf{N}$ & $\%$ \\
\hline Female & 11 & 85 & 27 & $50 \%$ & 0 & 0 \\
\hline Male & 2 & 15 & 27 & $50 \%$ & 12 & 100 \\
\hline Total & 13 & 100 & 54 & 100 & 12 & 100 \\
\hline
\end{tabular}

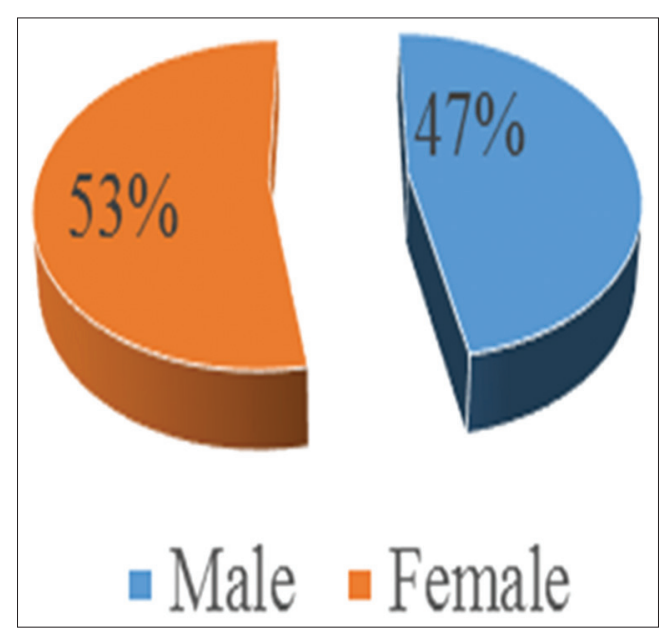

Figure 1. Gender of Students 


\section{Response Rate}

A total of 98 students participated in this study which represents a maximum $(100 \%)$ response rate.

\section{Gender of Students}

The findings show that majority $53 \%(n=52)$ of the respondents were females while the male respondents accounted for $47 \%(n=46)$ of the participants. The findings, therefore, show that both genders are well represented in the study.

The findings show that there is a significant relationship $\left(\chi^{2}=18.143, p<0.05\right)$ between gender and the language used by students in communication with friends of the same sex. The findings also show that there is a significant relationship $\left(\chi^{2}=13.144, p<0.005\right)$ between gender and the language used at school. The finding, therefore, clearly demonstrates that gender influences language shift. This is in agreement with the findings of Labov (2001), Eckert and McConnell-Ginet (2003), Winter and Pauwels (2005) and Meshtrie et al. (2009) who also found statistically significant relationships between gender and language shift. The finding is, however, in disagreement with Granhemat, Abdullah, Heng and Tan's (2015) study where gender is not found to be a determinant of language choice in the transaction domain of language use. Cross tabulation of gender and language used by students in communication with friends of the same sex was conducted to enable the study gain a deeper understanding of the said relationships.

The findings show that majority $(85 \%)$ of those students who use English in communication with friends of the same sex are females. The findings also show that $(100 \%)$ of those who use Sheng in communication with friends of the same sex are males. Therefore, female students are more likely to use English while male students are more likely to use Sheng in communication with friends of the same sex. This finding is in agreement with Hamdani's (2012) argument that females are more likely to use code-mixing than males. However, the finding is in contrast with Clyne's (2003) postulation that males shift to majority language faster than women. The table below highlights the results of the cross tabulation of gender and language used by students in school:

The findings in Table 4 above show that majority of those who use English (56\%) or both English and Kiswahili $(64 \%)$ are females. The findings also show that majority of those who use Kiswahili (62\%), Sheng (100\%), English and Sheng (100\%) or Kiswahili and Sheng (100\%) are males. The findings, therefore, show that in school, female students are more likely to use English while male students are more likely to use Sheng. Kiswahili is used equally among males and females while mother tongue is not used at all. The finding shows that female and male students use languages differently and therefore, language shift occurs differently between the two genders. This finding is in agreement with Nicholas' (1978), Murkherjee's (1996, 2003), Clyne's (2003) and Wardhaugh's (2006) view that there is a significant distinction in the use of language along gender lines. Similarly, Kamwangamalu (2000) cites a typical trilingual scenario in an urban Kenyan context where boys use mother tongue or ethnic language at home, Kiswahili or Sheng at play and English at school or church. The finding is, however, in disagreement with Granhemat's, Abdullah's, Heng and Tan's (2015) opinion that gender is not a determinant of language choice in the transaction domain of language use.

\section{CONCLUSIONS AND RECOMMENDATIONS}

The study set out to assess the nexus between the gender variable and language shift among the youth in Nairobi County, Kenya. The study found that the youth in Nairobi County use mother tongue in limited domains such as at home or when their parents visit their schools. There was a significant relationship $\left(\chi^{2}=18.143, \mathrm{p}<0.05\right)$ between gender and the language used in communication with students of the same sex. There was also a significant relationship $\left(\chi^{2}=13.144, p<0.005\right)$ between gender and the language used at school.

Based on the findings and discussion above, the study concludes that gender plays a significant role in language shift among the youth in Nairobi County. This is because boys differ from girls in the use of various languages where female students are more likely to use English while male students are more likely to using Sheng in communication with friends of the same sex. In school, female students are more likely to use English while male students are more likely to use Sheng. Kiswahili is used equally among male and female students while mother tongue is not used at all.

The study recommends that the Ministry of Education relaxes current policy to allow for communication in mother tongue among students in school. This will prevent loss of mother tongue languages and culture. The language policy makers can also consider offering mother tongue languages as optional subjects in both basic and higher education. Researchers in the field of education should conduct studies to find out the best practices on how mother tongue can be used alongside English and Kiswahili without the former affecting performance of students in English and Kiswahili. In addition, future research should also focus on a comparison between rural and urban statistics to see whether language shift is more of an urban than rural phenomenon. Research should also explore ways of controlling this shift and thus maintaining indigenous languages.

Table 4. Cross tabulation of gender and language used by students in school

\begin{tabular}{lcccccc}
\hline & Eng & Kis & Eng+Kis & She & Eng+She & Kis+She \\
\hline Female & 58 & 38 & 64 & 0 & 0 & 0 \\
Male & 42 & 62 & 36 & 100 & 100 & 100 \\
Total & 100 & 100 & 100 & 100 & 100 & 100 \\
\hline
\end{tabular}




\section{REFERENCES}

Airasian, P. W., \& Gray, L. R. (2000). Educational research: Competences for analysis and application. New Jersey: Prentice Hall.

Babane, M.T., \& Chauke, M.T. (2016). Xitsonga in language shift: A sociolinguistic approach. Journal of Social Sciences, 47(1), 49-57.

Batibo, H.M. (2005). Language decline and death in Africa: Causes, consequences and challenges. Clevedon U.K: Multingual Matters Ltd.

Bartoo, P. J. (2009). Language change and social networks among Somali refugee teenagers (Unpublished Doctorate Thesis), University of Witwatersrand, South Africa.

Brenzinger, M., Heine, B., \& Sommer, G. (1991). Language death in Africa. In R.H. Robins \& E.M. Uhlenbeck (Eds.), Endangered languages (pp. 19-44). Berg: Oxford.

Clyne. M. (2003). Dynamics of language contact: Cambridge: Cambridge University Press.

Cohen, R.J., \& Swerdlik, M.E. (2005). Psychological testing and assessment ( $6^{\text {th }}$ edition). New York: McGraw Hill.

Eckert, P., \& McConnell-Ginet, S. (2003). Language and gender. Cambridge: Cambridge University Press.

Fishman, J. A. (1972). The sociology of language: An interdisciplinary social science approach to language in society. Rowley, MA: Newbury House.

Fishman, J.A. (1977). Language and ethnicity. In H. Giles (Ed.), Languages, ethnicity and intergroup relations (pp. 15-57). London: New York Academic Press Inc.

Fishman, J. (2004). Language maintenance, language shift and reversing language shift. In T. K, Bhatia \& W.C. Ritchie (Eds.), The handbook of bilingualism (pp. 406436). Maiden/Oxford/Carton: Blackwell.

Fraenkel, J., \& Wallen, N. (2000). How to design and evaluate research in education. San Francisco: McGraw-Hill Company.

Githiora, C. (2002). Sheng, peer language, Swahili dialect or emerging Creole? Journal of African cultural studies, 15 (2), 159-181.

Granhemat, M., Abdullah, A. N., Heng, C. S., \& Tan, H. (2015). The influence of gender and ethnicity on the choice of language in the transaction domain of language use: The case of undergraduates. International Journal of Applied Linguistics and English Literature, 4 (5), 249-254.

Hamdani, F. (2012). The influence of gender in determining the language choice of teenagers: Sudanese versus Bahasa. International Journal of Basic and Applied Science, 1(1), 40-43.
Kothari, C. R. (Ed.). (2004). Research methodology: Methods and techniques. New Delhi: New Age International Publisher, India.

Kathuri J., \& Pals, A. (1993). Introduction to educational research. Njoro: Egerton University Press.

Kamwangamalu, N. (2003). Social change and language shift in South Africa. Annual Review of Applied Linguistics, 2(3), 225-242.

Labov, W. (2001). Principles of linguistic change. Oxford: Blackwell.

Leedy, P. D., \& Ormrod, J. E. (2005). Practical research: Planning and design ( $8^{\text {th }}$ ed.). Upper Saddle River, NJ: Merrill Prentice Hall.

Mesthrie, R., Swann, J., Deumert, A., \& Leap, W. (2009). Introducing sociolinguistics $\left(2^{\text {nd }}\right.$ ed). Edinburgh: Edinburgh University Press.

Michieka, M. (2005). English in Kenya. A sociolinguistic profile of English in Kenya. World Englishes, 24 (2), 172-186.

Mugenda O. M., \& Mugenda, A. G. (2003). Research methods: Qualitative and quantitative methods. Act Press. Nairobi.

Murkherjee, A. (1996). Language maintenance and language shift: Panjabis and Bengalis in Delhi. New Delhi, India: Bahri Publications.

Murray, T. R. (2003). Blending qualitative and quantitative. Research methods in theses and dissertations. Thousand Oaks. CA: Corwin Press.

Nicholas, P.C. (1978). Black women in the rural South: Conservative and innovative. International Journal of the Sociology of Language, 17, 45-54.

Ortman, J. M., \& Stevens, G. (2008). Shift happens, but when? Inter-and intra-generational language shift among Hispanic Americans. Population association of America 2008 annual meeting programme. Retrieved from http://paa2008.princeton.edu/papers/80685

Orodho, J. (2005). Education and social sciences research methods. Nairobi: Harlifax Printers.

Trudgil, P. (2003). A glossary of sociolinguistics. Oxford: Oxford University Press.

Tsitsipis, D (1998) A linguistic anthropology of praxis and language shift: Arvanitika (Albania) and Greek in contact. Oxford: Clarendon Press.

Wardhaugh, R. (2006). An introduction to sociolinguistics. UK Blackwell Ltd.

Winter, J., \& Pauwels, A. (2005). Gender in the construction and transmission of ethnolinguistic identities and language maintenance in immigrant Australia. Australian Journal of Linguistics, 25, 153-168. 